\title{
Society, Dispersed Knowledge and Uncertainty Toward Ethical Tales
}

\author{
Przemysław Zonik \\ (independent scholar; Lublin; pzonik@runbox.com) \\ ORCID: 0000-0001-6141-7932 \\ Joanna Zonik \\ (independent scholar; Lublin; zonikjoanna@gmail.com) \\ ORCID: 0000-0002-3006-4246
}

\section{Introduction}

A minimalistic model of private property assumes that people can own something they have found, provided it did not belong to anybody before it was found. Against it, an argument "from the common good" can be presented, ascertaining that it is not possible to find anything that belongs to nobody because Earth is the property of all people. From this point of view, a statement that in any time and place there is anything unowned that can be found is false. It is so because, according to the concept of the common good, there is a permanent state of possession of any part of the Earth by each and every human being, and thus, it is not possible for a single person to possess any part of the Earth without violating the proprietorship to this part of all the others1 (see Cohen 1995, 67-91).

This type of argumentation, "from the common good", reappears repeatedly within various ethical theories and their sociopolitical extensions. In the most general sense, the common good is the highest value that comprises a moral criterion for evaluation of human actions. It is an ontological basis and a benchmark for ethical theories (following Tadeusz Czeżowski that "the object's value should, from the ontological point of view, be

1 Cohen introduces his idea of a common good argumentation in order to critique Nozick's idea of private ownership. Nozick's general idea of how his research and argumentation should be done in the field of political philosophy looks like this: "A theory of a state of nature that begins with fundamental general descriptions of morally permissible and impermissible actions (...) and goes on to describe how a state would arise from that state of nature will serve our explanatory purposes, even if no actual state ever arose that way" (Nozick 1999, 7). By making this statement (empasized in italics) Nozick admits that it is fine to use speculation instead of analysis based on the ontology of the real world. Conclusions extrapolated from that speculation he considers valuable and explanatory. Such leaving aside of the world's properties does not make a theory, that is intended to apply to the world, explanatory. It only accumulates the number of epiphenomena in the form of subsequent levels of abstraction, which, in turn, make it impossible to clearly understand the theory's true reference. Cohen, however, in his criticism of Nozick, uses the arguments of the exact same origin and thus, fights against speculation with speculation based on contrary assumptions. 
understood analogically to that object's existence") (Czeżowski 1989, 97).²

In harmony with this concept, further values and ethical norms are formulated, however, if they negate or cannot be harmonized with the idea of the common good, they are excluded from those theories. It seems that the concept of the common good expresses some type of moral attitude, based on which new ethical claims are formulated, and then those claims become criteria for the evaluation of people's actions in practical domains e.g. in politics and economics. Both these domains comprehend a very large range of human actions and, for this reason, an ethical theory pretending to be universally obligatory in the domain of politics and economics must deal successfully with the consequences of people's actions.

This paper has two main goals. The first is to analyze the common good line of reasoning by explicating its assumptions, structure and consequences in both formal and material aspect. The second goal is to show that the common good argument exemplifies a specific type of ethical line of reasoning (ethical tales). We call it ethical tales because they seem to be narrations that are prone to the error of misreference like fairy tales which do not picture the real world.

\section{Complexity of Nature's States}

The ontology that we base our line of reasoning upon, we call "the theory of complexity of nature's states". By a nature's state we understand a physical phenomenon that is a system (an arrangement of relation-connected elements). Although the world

2 Our primary meta-philosophical assumption is that ontology plays a key role in theoretical thinking expressed in the form of signs. Each of these kinds of thinking (e.g. epistemological or ethical thinking) are based on the explicite or implicite assumptive existence of the object to which the theory's sentences refer. The domain of reference may be fictional but it cannot be empty, because it is not possible to say about nothing (our metaphilosophical approach does not prejudge the real reference of a given ontology). When Gorgias claimed that "there is no-thing", he treated the "no-thing" as an entity (what follows from the subject-predicate structure of the sentence). Therefore, each formulation of a belief in the form of an indicative sentence engages ontologically. For example, the " (...) forming of the feeling of value is preconditioned (...) by the conviction that the object of the feeling exists (...) unrelated by no dependence to the value's estimation, that can also be formed with reference to non-existing object" (Czeżowski 1989, 99). Our meta-philosophical approach can be understood as an interpretation of the law of non-contradiction. In contrast to the way Jan Łukasiewicz explicated the Aristotelian psychological law of non-contradiction (Łukasiewicz 1987, 11-13), we think that this kind of contradiction is often present and visible in people's thinking. The reason for this is having partial, incomplete knowledge. By contrast, in the field of the theory of communication and pragmatics, where we deal with thoughts expressed in sentences, the law of non-contradiction does not seem to be in force. If somebody expresses a sentence in which they claim something that is contradictory, then they gibber, say things without sense (they attribute some contradictory features to the object), so that, in effect, we are unable to understand this sentence (Bocheński 1994, 28-29). The existential status of paraconsistent logics and dialetheism also needs explanation. The former was created in order to clarify the description of contradictory information; therefore, they simply formalize gibber. Dialetheism, in turn, negates the law of non-contradiction and assumes the existence of dialetheia, that is, a sentence that is true, false and meaningful at the same time. Owing to the fact that it is not possible to give any example of such a sentence, it should become clear that the doctrine of dialetheism is an example of the non-obligatory status of the law of non-contradiction in the field of psychology (see Tkaczyk 2014, 23-35; Priest \& Berto 2017). 
is subject to entropy, a great part of nature's states is characterized by high durability (steadiness). The great majority of those states is not a human composition - artifacts, but have come into existence spontaneously as a result of natural energomaterial interactions - they are orders. The orders' durability and robustness results from their structure - the fact that they consist of many highly specialized subsystems, which counteract the loss of control.

Every order is a kind of mechanism, that is, a system of cause-and-effect relations. We consider that the concept of causality is a derivative of the existence of mechanisms in nature and that statements about causality are in fact statements about the existence of mechanisms. A connection between a cause and effect is a mechanism and particular mechanisms describe particular cause-and-effect relations (Glennan 1996; Crean 2010).

Thus, what is responsible for the functioning of a system as a whole is its intrinsic mechanism. The model of a mechanism is a description of an order's organization. Models of mechanisms describe the connections between the variables referring to various parts of the systems in the world. ${ }^{3}$ A system's structure is what makes it work the way it does as a whole (e.g., birds fly and people don't - which is the direct consequence of their structure). Natural systems have different levels of their structure's organization (e.g., physical, chemical, biological, social). The mechanism of the functioning of a lower level of organization explains the system's functioning on higher levels (e.g., electricity is explained as the movement of charged particles), that is, the causality of a given level of organization is explained by the lower level's mechanism. Decomposition of mechanisms can be performed until we reach a certain basic level of matter's organization, which itself cannot be decomposed into causal mechanisms. ${ }^{4}$ The cybernetic approach that we present here (i.e., naturalistic, systemic and mechanistic) can be applied to the description of any phenomena of different levels of reality including idiographic phenomena. ${ }^{5}$

3 An important matter of mechanistic approach is to understand how parts constitute a unity. We agree with Stuart Glennan that the minimal mechanism describing a phenomenon consists of parts and those parts' organization (activity, interactions) creates that phenomenon. In other words, the mechanism of behavior is a complex system that creates that behavior through the interaction of some parts of it. Those parts, apart from having a fixed place in the system, must be stable enough to consider them as autonomous objects. It must be, then, possible to separate them and consider their properties in a different context (Glennan 2002). A mechanistic model must, thus, consist of: (i) a description of a mechanism's functioning (behavior description), and (ii) a description of a mechanism that explains that behavior (the mechanical description) (Glennan 2005).

4 By this we mean the lowest "atomic" level where causality can be applied. It may be that at the subatomic level, causality in a macroscopic sense is absent (e.g., according to Glennan, mechanistic theory can be applied to the levels above the quantum level). We should remember that atomic level phenomena cannot be fully explained without reference to the subatomic level (e.g., electricity). This is connected to the question of the limits of our cognition and to the trust we put in contemporary dominant theories (Kuhlmann \& Glennan 2014; Falk 2016; Gryziński 2002).

5 There are two kinds of mechanistic models. The first kind is a genetic model (etiological model), which describes the history of a given phenomenon, its site in the historic sequence of causes. In turn, the structural model (constitutive model) explains the phenomenon by the description of its structure (internal causal structure). Two types of mechanisms must also be discriminated: stable (based on the arrangement of their parts that are characterized by visible repetitiveness, e. $g$. human) and ephemeral (which include the processes evolving in time without a fixed time-spatial arrangement, and often non-recurring e. g. some cell mechanisms, historic events). Each natural phenomenon is a certain sequence of changes, a process. Some causal patterns are repeatable (e.g., 
The ontology of the real world presented in this paragraph will be the basis of the analysis of the society in the next paragraph. Mechanistic explanation of the society avoids two main errors of social theories: individualism (which is not able to speak about the society as a whole) and holism (which is unable to explain social changes). In the next paragraph we will explain how a society can be understood in terms of mechanism.

\section{Society As a Mechanism - An Outline}

We define a society as an order composed of interacting and relation-connected individuals who have subjective knowledge. The most fundamental feature of such a system will be its multilevel decentralization, which is the consequence of the dispersion of knowledge within this system.

Mechanisms related to the dispersion of knowledge allow people within a decentralized society to adapt to the natural conditions more effectively than they would be able to do within its atomized or centralized state (although it should be noted that the latter two are only a parte mentis beings). ${ }^{6}$

The development and adaptation of a human society to the local conditions have their own history in the form of genetic mechanisms. Those mechanisms are associated with the development of various relationships between individuals, formation of various social groups (societies' subsystems), and the embedding and dying out of certain behavior patterns etc. The process of adaptation has also been associated with the progress of culture and - when expanded to hominids - brain size development (encephalization). During cultural development, specific social institutions emerged, which coordinated social actors' behavior. Among these institutions are, for example, moral systems and economic systems (associated with private property and trade).7 The decomposition of social processes into a series of subsequent intersections would show that each such intersection contains the unique distributions of behavior patterns as well as the relationship topologies between individuals.

Social institutions have their source in the actions of individual people but they are more than just a sum of individuals' actions - they are indeed the unintended effects of those actions. In other words, social institutions are irreducible to individuals' behavior because they are of an emergent nature. The presented conceptualization of cooperation

the motion of planets) while others are idiographic events (e.g., Adolf Hitler's rise to power). The latter are less robust and stable than the former (Glennan 2010).

6 These kinds of out-of-touch-with-reality abstractions, like the aforementioned states, have been exaggerated in the narration of modern philosophers. The special part in this case was played by Thomas Hobbes who, under the influence of History of the Peloponnesian War by Thucydides, wrote his famous work Leviathan, which is an abstract validation of the existence of central power (Shalins 2008). In reality, there were no places where such nature's state as a "war of all against all" (Bellum omnium contra omnes) existed. This is confirmed by archaeological and anthropological research (Widerquist \& McCall 2015).

7 Institutions should always be regarded in terms of particular conditions of time and place (see, e.g., Anderson, Benson, \& Flanagan 2006; Pranke \& Zečević 2016). 
allows a consideration of social institutions as higher level information processing systems. Participation in these complex systems can be considered an extension of the compute capability of social actors' neural networks. When individuals' knowledge states become co-dependent (they received feedback, in cybernetic terms) then the entropy of the entire system (institution) decreases i.e. becomes smaller than the sum of entropies of individual elements of a social system. The entropy decrease causes the growth of the level of social organization. Thereby, social institutions are of a negentropic nature, opposing entropy growth within the society.

The functioning of institutions is, to a great extent, based on the imitation of behavior of some people by others. Thus, institutions harmonize and coordinate human cooperation without creating unnecessary communicative situations. Equilibrium tendencies are accompanied by kaleidic (kaleidostatic) processes of discoordination in the form of endogenous interference (changes in knowledge and views of social actors that result in certain behavior) and exogenous interference (changes in the behavior of others and the environment).

Both equilibrium and disequilibrium result in continuous, lesser or greater, changes in the social structure. Because of this continuous change of the structure, we are unable to imagine what our civilization will be like in 500 or even in 50 years, just like our medieval ancestors or our grandparents were unable to predict our way of living. A continued interaction goes on between our conscious pursuit of goals that we imagine as achievable, and the functioning of institutions, traditions and habits (Hayek 1978, 24).

We could say that the societies of humans and ants are in principle indistinguishable. Both systems come into existence as the result of the interaction between an enormous number of elements and both are based on stigmergic processes of self-organization. What makes a great qualitative difference between the shape of both systems is the completely different cognitive structure of their agents. The structure of a basic element of a social mechanism - a human being - explains why human societies are characterized by such great structural complexity and elasticity.

\section{Two Types of Uncertainty Within the Dispersion of Knowledge}

Mechanical description of society is closely related to the notion of the dispersion of knowledge from which two types of uncertainty follow. The uncertainty impacts on the way people think about the world, formulate sentences (including ethical reasonings).

The dispersion of knowledge means that each member of society has a certain, relativized to their own memory state, "portion" of knowledge, which is different from the knowledge of others, is not necessarily consistent with the knowledge of others and is unable to unify with it. The impossibility of knowledge unification is the result of its subjective character and the specificity of cognitive processes from which it follows. In the neurobiological aspect, knowledge is a class of states of a neural network of an 
organism. These states should be seen as a resultant of genetic load and the influence of the environment. In the development of such complex systems like the human cognitive system, the last element is especially important.

A human being, during their lifetime, recognizes their local environment (that is characterized by certain conditions of time and place) through a set of representations that are homomorphic (and not isomorphic, in the mathematical sense) projections of that environment in the nervous system, which means that there is no mutual equivalence between the representations and the environment. Above the basic unimodal level of representations, subsequent levels are overbuilt (" $n$ " degree representations). Different forms of representations are, at the same time, different forms of knowledge. Cognition is, then, limited by the structure of a cognitive subject. ${ }^{8}$

Representations directly influence the values that a subject holds, the goals that a subject sets for themselves and the decisions they make. Knowledge, then, determines the way of human behavior. It is subjective and discreet and, in consequence of it, human preferences, values and goals are also subjective and discreet. This means that each member of a society is able to pursue the realization of, exclusively, their own interest, i.e., to act in their own interest, according to their personal beliefs (which include, for example, taking into account the interests of others or reducing one's own consumption - generally taking into account the subjective preferences of others). ${ }^{9}$ Thus, each of us has two manners of behavior to choose from. Either we negotiate with the other side the range and the goal of our cooperation or we subordinate the other side to us with the use of threat and force. ${ }^{10}$

The first kind of uncertainty that results from the structure of human beings is ontological uncertainty. The model of the world, on which a human operates, is, in fact, only an incomplete projection of the energetic interactions (causal mechanisms) present

8 The neurobiological way of understanding knowledge (resp. memory) defines what it is in the most primal sense (what it means, that a subject knows something). It is possible to present different kinds of knowledge on that basis, e.g., justified and unjustified beliefs, true and false beliefs, skills and propositional knowledge etc. When writing "knowledge" we use a mental shortcut, because knowledge is inseparable from the cognogenic processes occurring in the brain. Representation means mapping in the form of synaptic connection chains in the brain and it has not only a layered but also dynamic character. Cognogenic processes occurring in the cortex (they can resemble Leibniz's "nissi intellectus ipse") have their basis in the electricity flow, and are genetically programmed, but this does not mean they are completely deterministic. There is a kind of randomness input into the knowledge processing, maybe even in its most primary form, i.e., in the form of drawing (in this case it would be better to speak of a sort of implementation of probabilistic algorithms in the cortex). For a certain state of neural networks that process the input, there are many paths of change of those states allowed. This is why each human has a different memory network (a different model - connectome). Moreover, the processing of representations in the brain is continuous through the entire life; it is dispersed and occurs simultaneously (in a multilayered fashion) (see Glimcher 2003; Gold \& Shadlen 2007; Fuster 2013; Tervo, Proskurin, Manakov et al. 2014).

9 It is so, insofar as a human remains a relatively isolated complex system, that is, as they meet the term of isolation: the environment's influences on a human being and vice versa occur through a human sensorium, i.e., their "inputs" (receptors) and "outputs" (effectors) (Greniewski 1959, 11-12).

10 The first option does not exclude different forms of self-defense and the defense of others (Long 2006). 
in the environment, which, in turn, are the result of the energoinformational asymmetry between a person (a finite energoinformational system) and the world (a conglomerate of energoinformational processes). This kind of ontological uncertainty is a constantly present feature of energomatter because, within it, the existence of omnipotent systems that exceed their own energoinformational capacity is not possible. Through modeling (cognition), we can take into account only some of the properties of the objects in the world, and this is due to our situation in the world and the cognitive limits resulting from this situation. Modeling requires selection of some variables and giving up of others. The identity of the model and the original is not possible because of the three following factors:

(i) simplicity of the model in regard to the original,

(ii) the existence of certain properties of the model that the original does not have,

(iii) the indeterminacy of the original.11

Energoinformational cognitive restrictions and the ontological uncertainty connected to it have serious practical consequences. A human, when focusing on a certain part of the world, after a closer analysis of what seems to be intuitively understandable, discovers that it is in fact a bunch of problems that need to be divided, in the next step, into constituents. Analysis of the constituents, analogically, generates a whole range of problems. Thus, the original inquiry becomes a point generating a range of the following inquiries, which often interfere with our previous knowledge or become informatively overwhelming (Klawiter 2004; Dennett 2007). The consequence of this is that we often merely dispose of a general concept of "how something works," and any trial of the explication of the phenomena in the mechanistic terms is difficult.

Thus, the most important consequence of ontological uncertainty is that our knowledge of the recognized phenomena is, and will be, necessarily partial. Even the heterogeneous sphere of our closest environment that we know fairly well, at a given time, appears to be static and homogeneous. Any cognitive procedures that define how we increase our knowledge of the world need to tacitly assume the expandability of the investigated problem (as described in the previous paragraph). Everything that we do not know (even in the form of explanation in principle) makes the world around us amorphous.

The second kind of uncertainty is epistemological uncertainty related to human actions in time. Humans have evolved thanks to the mechanism of natural selection (trial and error) and their minds (the cognitive structure) have not been "designed" directly

11 "The more a model (...) and the original converge in the area of certain simulated variables, the more they drift away in the area of other variables (...) If we wanted to model any phenomenon including all its variables (assuming, for a moment, that it is actually possible) we would have to build a construct richer than the original in respect of those additional variables which are specific to the modeling system itself, and which the original doesn't have" (Lem 1964). Therefore, there exist more and less precise models (models can be improved). Whether a model is precise enough is often based on expediency (Glennan 2005). 
for systematic examination of the world, but for navigation in the environment. Evolution rewarded abstract thinking only if it turned out to be useful in the course of that navigation. Thus, the mechanism of reasoning simplifies remembering but, at the same time, it does not let the cognitive structure become overloaded, which is related to inductive reasoning (coming from a number of details to a generalization). As such, analytical-critical thinking is not innate in humans. In everyday life practice, we unceasingly overestimate the precision of our own judgments and we show the lack of elasticity when we hang onto one-time made decisions, and we underestimate the ontological depth of events we participate in (their expandable nature). At the baseline (but not necessarily ultimately), we are ruled by Keynes' "animal spirits" taking form of emotional-associatory bonds. We trust our feelings ("judgments") and we reject the idea that all this may lead us to a mistake. ${ }^{12}$ What we have to do with is a sort of generalized availability heuristic. ${ }^{13}$

The epistemological uncertainty reveals itself at the moment of predicting the future (which is evolutionarily necessary for survival). Social structure is continuously changing, and the minimal model of change can be understood as a transition from state S1 to the following state S2. As Joseph Schumpeter (creative destruction), George L. S. Shackle (kaleidics) and Ludwig Lachmann (kaleidostatics) noticed, the transition between those states may be dynamic and result in great structural differences. In state S1, people have expectations concerning the future and make their decisions on that basis. The consequences of those decisions can be elusive if the expectations fail to meet the reality. On the one hand, the failure is caused by the fundamental character of the cognition, and on the other hand, by the chaotic (in a deterministic sense) nature of socioeconomic phenomena at the present level of the evolution of culture (many things seem obvious ex post). The epistemological uncertainty is, then, the main factor in the aforementioned processes of discoordination.

Therefore, the concept of dispersed knowledge has two linked understandings of uncertainty. The first, ontological, is the consequence of the structure of the world and people. The second, epistemological, is related to people's expectations concerning the future. It should be noted that in both cases the states of uncertainty in subjects are not being reduced, even when new information is provided or when improved procedures are applied. In the first case, it is a reminder of determining a particle's position and momentum at the same time, and in the second case "we simply do not know" and we can get lucky at best (Taleb 2007).

Both kinds of uncertainty are present in our language. The way we formulate

12 "Recall that someone with only casual knowledge about the problems of randomness would believe that an animal is at the maximum fitness for the conditions of his time. This is not what evolution means; on average animals will be fit, but not every single one of them, and not at all times. Just as an animal could have survived because its sample path was lucky" (Taleb 2001, 82; Keynes 2013, 161-162).

13 People apply their own measures to the world; they count the probability of future events using their own representations of past events recovered from their memory (Kahneman, Slovic, \& Tversky 1982, 11-14). 
sentences reveals the great area of our ignorance. In the sense of ontological reference, the sentences we create often have very shallow or no reference to the reality. Those sentences say nothing although we think they do (e.g. "What exists? Everything."). The abstract notions that we use lead us down a blind alley right toward false predictions, decisions and unintended consequences. It could be said that, due to the use of language, a human is a pseudo-omnipotent being, as we use general abstract words and ostensible reasonings, which refer to nothing in the real world or to something very general and, in effect, inconclusive. This is a common enough feature of all people to call it a collective representation. The words that they use might differ but the domain remains fictional.

Regardless of whether one is a private property or common good supporter, one needs to provide a detailed account of what the objects are that one has in mind when making statements about them.14 It is not sufficient to use certain words, because those words may have no reference in the physical world or the reference may be different than assumed.15 W. V. O. Quine put it succinctly and accurately: "What there is does not in general depend on one's use of language, but what one says there is does" (Quine 1961, 103).

In the next two paragraphs we will analyze what is the possible definition, meaning and reference of the common good concept.

\section{The Definition of the Common Good}

Private property opponents put forward an argument that private property is an indefensible concept because the objects it most often refers to, namely the Earth's resources, land etc., cannot be owned in the way that private property defenders see it, as they are, in reality, something that belongs to everybody - a common good. The object of reference of both sides is, then, explicitly defined: it is the Earth and its parts. Common good reasoning may be paraphrased like this:

The common good is something that is owned by all people.

The Earth is a common good.

The Earth is owned by all people.

In the above reasoning, both the Earth and people belong to the same domain, namely, the class of physical objects in space. Generally, we consider the Earth a mereological set and thus, we consider all the resources a part of this set. To simplify, however, we adopt

14 What was meta-ontologically unimportant becomes ontologically important, as far as we want to say something about the world of energomaterial interactions and not to hang back in the world of our own fantasies (see footnote 2).

15 Ludwig von Mises, for example, claimed that his praxeology is a deductive science, similar to mathematics, while it is not. It is definitely a narration, a reasoning, but not all reasonings are deductive (deductive reasoning must meet certain strict conditions). 
the definition where, instead of the Earth, we refer to a set of the Earth's resources (a traditional set). This leads us to the following paraphrase:

There exists a set of the Earth's resources, which are a common good and are owned by all people.

Precisely, what we have here is a relation of ownership (property) between a set of resources and a set of people. The idea behind the concept of the common good is that each element from the set of resources can be assigned using the relation of property to every element from the set of people.

In the next paragraph we provide characteristics for each of the sets (resources, people) and the relation (property), as well as analyze the presented reasoning based on the content of the previous paragraphs.

\section{The Reasoning's Analysis}

The idea of the common good - if it wants to be materially binding - cannot disregard the real properties of the objects it refers to in the above paraphrases as well as the character of the relation itself.

The first element of the relation of ownership in the introduced paraphrases is a set of the Earth's resources, which can be understood whether as a whole, that is the Earth, or partially, as its specific parts. The main characteristic of the resources, resulting from their nature, is scarcity.

The (...) fact is that there exist some things which are sufficiently scarce that they cannot be used by everyone as much as each would like. We cannot all have everything we want. Therefore, in any society, there must be some way of deciding who gets to use what when. You and I cannot simultaneously drive the same car to our different homes. (Friedman 1989, 4).

The second element of the relation is the set of individuals understood as relatively isolated complex systems limited in their actions by the laws of physics and their consequences (i.e., society as a mechanical nature state) and by their own beliefs. As David Friedman said: "Whether they are misers or saints, the logic of the situation is the same; it remains the same as long as each person, observing reality from the distinct vantage point of his own head, reaches a somewhat different conclusion about what should be done and how to do it" (Friedman 1989, 4).

The relation of ownership can be expressed this way: when we say that something is someone's property, it means that that person, as the owner of that thing, may dispose of it at will. When someone may not dispose of a thing at will, because of the principles imposed from above by the third party, and when someone is forced to comply with those 
principles under the threat of punishment, then they are not the owner of that thing but merely a sort of provisory user of that thing.

The definition of the common good states that all people are the owners of that good - in our case, Earth, which is a set of resources. This is problematic because according to the definition of resources, a question arises how people, scattered all over the world, would be able to dispose of something that is beyond their physical, temporal and conceptual reach. It could be said that the Earth's resources are everybody's ownership but this would mean some sort of nominal "property" without any binding factual or legal consequences, as this is not possible to rationally meet the condition of all people expressing their will to dispose of the Earth's resources all at the same time. ${ }^{16}$

Moreover, the reasoning presented above suggests that there occurs a simultaneousness of exclusive disposal (ownership) and, at the same time, nonexclusive disposal ("common" introduced by the pronoun "all") of a certain object. This is contradictory (not in logical sense though).17 Therefore, the understanding of the term "to own" must be in this case different from the standard concept of private property; the common good concept defenders have something else in mind when they say that something is owned by all people. Otherwise this postulate would be indefensible in both a formal and material respect. In reality, there is no "property" relation in the concept of the common good. This means that, on the ground of the common good concept, the relation between the set of resources and the set of people is a relation of a different kind of disposal of resources than the exclusive disposal of the owner.

Incommensurability of the elements in the definition of the common good expresses the epiphenomenal character of the entire concept. In order to remove the contradiction, we would have to adopt an unrealistic characteristic of the resources as an indefinite18

16 This difficulty concerns the compromise regarding the access to resources (controlling the resources) as well as co-ownership. It is not essentially possible for two people to dispose of the same object at the same time but they can set some shared conditions of that disposal in a fixed time. This problem seems insolvable in global conditions, but in local conditions, it can be overcome in many ways. In the simplest social systems, for example, Native American societies (e.g., Yurok, Hupa, Karok), private property plays a basic role. "The emphasis on private property may seem surprising to those who think of tribal society as some sort of socialism or communal system. On the contrary, however, private property rights are common characteristics of primitive societies; they constitute the most important primary rules of conduct. After all (...) law enforcement (secondary rules of recognition and adjudication) arose through voluntary cooperative arrangements" (Benson 1989, 8; Waterman 1920, 182-184 \& 218-223). In a welldeveloped system of institutional rules, it happens through voluntary agreements with clearly determined conditions reflecting the existing situation and some concept of equality; this will be some kind of legal or principled equality and not an equality in an absolute metaphysical sense of unqualified total co-ownership. See Ostrom (1990). From the evolutionary and cognitivist point of view, property rights (conventions, possibilities of "legal right to control things") stem from the mere fact of the ability to control certain things by individuals (property ownership) (Friedman 1994; Sugden 2005). Heidegger's terminology: Dasein has direct access to the things of the world.

17 The statement that all people dispose of the Earth's resources is often followed by an additional term: "in the same way". Such equality is impossible to achieve given, again, the characteristics of the relation's elements that we provided. Neither the resources are easily divisible nor is the possibility to possess them (because of their locality and time dependence) (Narveson 1997).

18 This is how Marx imagined it: "In einer höheren Phase der kommunistischen Gesellschaft, nachdem die knechtende Unterordnung der Individuen unter die Teilung der Arbeit, damit auch 
and/or different characteristic of people e. g. as a kind of Guild Navigator from Frank Herbert's Dune.

Therefore, we conclude that considering the real qualities of the physical objects, which the common good concept fails to capture, makes it impossible to explicate the idea of the common good in a clear and non-contradictory way. In order to eliminate the contradiction, let us reduce the numerical amount of the sets. This will probably lead us to legitimizing some form of property rights, which strikes at the essence of the common good concept. It is not conceptually and physically possible for everyone to own everything. The common good concept is, then, a naive nominal composition; it has, however, very important practical consequences when applied to the world. This will be the goal of the following paragraph.

\section{Practical Consequences of the Common Good Concept}

Because of a great number of people who act in their own interest, it is difficult to imagine a situation of full agreement regarding how to control a particular good. As there is no agreement, then the people who regard the common good concept as rightful and true have two ways out. The first one is the informational impact on the environment, namely, convincing the others of one's arguments, and, in effect, an attempt to voluntarily rebuild society.19 The other way is energetic impact, that is, compelling the others (by force or by the threat to use force) to live according to one's ethical norms. As long as the first one seems rather harmless, the other one can have serious practical consequences.

The risk associated with the second way of impact lies in the manner of seeking means to pursue one's goals within a state organization and is connected to the mechanisms of social control.20 Thanks to those two factors, a narrow group of people

der Gegensatz geistiger und körperlicher Arbeit verschwunden ist; nachdem die Arbeit nicht nur Mittel zum Leben, sondern selbst das erste Lebensbedürfnis geworden; nachdem mit der allseitigen Entwicklung der Individuen auch ihre Produktivkräfte gewachsen und alle Springquellen des genossenschaftlichen Reichtums voller fließen - erst dann kann der enge bürgerliche Rechtshorizont ganz überschritten werden und die Gesellschaft auf ihre Fahne schreiben: Jeder nach seinen Fähigkeiten, jedem nach seinen Bedürfnissen!" (Marx 2017, 21).

19 This a libertarian way of acting. Contrary to popular belief, libertarianism does not exclude socialism or communism, because the only thing it assumes is voluntarism. Owing to the fact that we are able to persuade to our rights a relatively small number of people, the reconstruction takes place only in local conditions in the form of experimental communities, for example. We can, however, wonder whether this kind of behavior is not a utopia, even in local conditions. For example, in 1825, a socialist, Robert Owen, bought a colony settlement in the south of Indiana from German radical, George Rapp. Owen tried to create a community based on the public ownership of the means of production ("New Harmony"). The experiment collapsed after two years, and one of its participants, Josiah Warren (initially an enthusiastic socialist), noted that collective property is the source of all social conflicts. "„The true basis for society is exactly the opposite of this. It is freedom to differ in all things, or the sovereignty of every individual" (Warren 2011,63). Many communities of this type (including "New Harmony") had a strong religious framework, so the participants' expectations were somewhat transcendent. This is an important premise for everybody whose expectations are immanent because it is doubtful whether even small communities are able to sustain economic stability in the long run.

20 Our way of thinking at a given moment results from our direct personal experience. As F. Varela 
acting in their own interest (e. g. according to the beliefs about the "common good" that are intrinsically contradictory, vague and completely out of touch with the reality) is able to impose some top-down behavior rules on the rest of the society, which will result, at best, in people's instrumentalization and, at worst, in terror and genocide. It is necessary to remember that the group in charge cannot pretend to have extraordinary knowledge of the world and its mechanisms, and certainly doesn't have knowledge of the local conditions in which all the other people operate. The last problem becomes especially urgent when very strong signals of society's disarray are coming from the environment (Chamlee-Wright \& Storr 2009; 2010). Politicians and experts are most often typical planners who do not consider the world's variability and the incomplete knowledge of the facts as well as the uncertainty of the effects of implemented operations.

Resource management within a political system still meets many difficulties. First, this kind of management takes place in certain specific conditions of the environment. The representatives aren't able to escape those conditions. Difficulties that they cope with, and that they do not clearly see, prevent them from rational planning that is supposed to lead to the implementation of any created ideals. Any tendencies towards greater decisionmaking centralization should be considered as the weakening of the mechanisms built-in by evolution into the social nature state. Society and the environment encounter each other in an unceasing interaction. This "dialogue" is an experimentation by trial and error. The essence of this process is a decision-making dispersion. Certain people are responsible for certain decisions and particular peoples' mistakes are not able to lead to the demise of the entire society. In other words, the ongoing self-organization processes (institutional coordination and discoordination) in society attempt to sustain its homeostasis. In the case of political decisions, the situation looks different, as those decisions are in fact an experiment based on the wrong sampling because they involve the entire population or its large parts (which are beyond the "experts'” comprehension). In effect, politicians are the ones who make decisions, but the people, of whose existence the politicians do not know, are the ones who bear the costs of them. ${ }^{21}$

said: “(...) cognition is dependent upon the kinds of experience that come from having a body with various sensorimotor capacities; and (...) individual motor capacities that are themselves embedded in a more encompassing biological and cultural context" (Varela 1999, 11-12). This, in turn, often entrails treating this experience as necessary. "Do you ever wonder why people believed in the divine right of kings, despite the fact that the monarchs of their time were patently not the type of individuals an all-knowing, all-good god would choose to reign over them? They believed in it because they were taught to believe in it and because they could imagine that it was so, regardless of all evidence to the contrary. We no longer believe in such silly things as the divine right of kings. We believe that government is necessary for an orderly peaceful society and that it can be made to function according to the rule of law. We believe this because we have been taught to believe it from infancy and because we can imagine that it is so, regardless of all evidence to the contrary" (Hasnas 2008, 130-131; see also footnote 2 in Block, Futerman, \& Farber 2016).

21 The effects of those kinds of decision-making are negative unintended consequences (Norton 2017). A great illustration of it is the so-called "help for Africa." More than US $\$ 1$ trillion of foreign aid has been transferred from rich countries to Africa over the past 50 years. This is nearly US\$1,000 for every man, woman and child on the planet today. Nevertheless, they have not helped to reduce the poverty, and neither have they stabilized economic growth (compared to Asian countries at that time) (Minardi 2017). This help has not been indifferent though; it has triggered 
The political implementation of the concept of the common good does not serve (is not able to serve) the concept of equality and universality. Its main goal is to justify and to legitimize a certain way of governing people and resources (in fact, it treats people as resources). Initially uncountable number of "co-owners" must be narrowed down in favor of certain representatives, which will make decisions on behalf of the rest of the people. Therefore, the concept of the common good is, in fact, the concept of a top-down organized access to the resources.

\section{About the Construction of Ethical Tales and Their Reference}

In this paragraph we would like to draw conclusions about ethical tales. Just like the theory of the common good misses its assumptions, similarly other ethical reasonings often have different reference from postulated. And just like a priori theories in natural sciences can fail to meet the experience, so can ethical ones. This in turn raises the question about the relation between obligatory and descriptive statements. This relation is also analyzed in the following paragraph.

Based on their structure and experience, people are equipped with a subjective model of the world. This model has an evolutionary derivation and serves, among others, to satisfy people's desires and needs through the interaction with the world.22 Humans are, however, always capable of doing or not doing something with a certain object of the world. Since the environment is practically an uncountable set of particularities, humans must find a way to figure out their determinants and adapt to them, otherwise they will die. Evaluations are what help humans to do this. Every time we want something, we evaluate it positively. "This happens especially when we are somewhat conscious that the desired phenomenon is able to meet our needs" (Koj 1998, 40).

It is evaluations that become the origin of ethical tales. Their form is that a certain person considers something as good or bad for them. These evaluations lead straight to obligations (ethical norms), which are a kind of propositions containing deontic functors like: "It is necessary", and "It should be that".23 These convictions should be seen as

a series of negative consequences: 1) a huge scale of corruption and, following it, politicization of the countries, 2) aid and aid-dependency: those in charge want to stay in charge, 3) "manna" falling from the sky has resulted in brutal conflicts (according to the Stockholm International Peace Research Institute, Africa is the most conflict ridden region of the world, and the only region in which the number of armed conflicts is on the increase), 4) institutional and organizational insecurity (in such conditions entrepreneurs will not make any investments), and 5) owing to the fact that economic growth is based on savings (reducing consumption) and excess following from it, the poor economies stay poor and poor people stay poor and threatened by conflicts. Comprehensive research on this subject has been done by Dambisa Moyo (Moyo 2009).

22 Desires are the part of subjective knowledge. A desire is, for example, a willingness to go to the cinema or play a game. Below desires there are needs, and satisfying those is necessary to live. Desires certainly rise from needs, but they are not reducible to them. For example, escaping from pain is a need, but the tragic, though admirable and memorable, decision of Janusz Korczak was his desire, standing against the primal biological need.

23 The structure of obligations from the logical point of view is investigated by deontic logic. Apart from standard modal functors, it also contains some deontic functors like: "it is permissible that" 
categorical statements, that is, containing subject and predicate, which in turn denote some things. The terms that build convictions are of an abstract nature, and transitioning from one of them to another is reasoning.

In the course of life, a classification of input takes place; inputs are endless in number and they constantly surround the sensorium of an organism since its very beginning. The body plays an important role of selector of representations in the neural networks. Classification is mostly unconscious as the great part of our knowledge is attained through imitation (more or less successful copying of others' behavior). A human being is, then, an adaptive classifying system. The basis of such functioning is continuous interpretation of the world through the input classification acts. Thanks to the expanded nervous system we can form meanings, that is, subjective and abstract interpretations of the environment. We set apart certain properties of the physical objects and we categorize those objects as elements of a certain class. Then, in actions, we use those abstract results of classification. Thus, the terms of natural language are founded in the body scheme (see footnote 27). Their basic level is characterized by a moderately low degree of abstraction, because they are created as a result of observation of events at a certain point in time and place. A human, when thinking, abstracts from the factors of time and place. Thus, the class of abstract terms and propositions lies over the class of idiographic terms.

Referring to the logical models of reasoning, abstractions used by humans could be presented as three overlaid matrices. A sense of the environment is rudimentary. and it corresponds with classical logic. Then, there is anticipation, which means that we need to add modal functors to the classical logic. On top, there is ethical thinking with its deontic functors. As mentioned, the realm of human thought is exposed to the contradiction. We could understand it in the following manner: If $\theta$ is a member of ZA set and $[\theta \rightarrow \varphi]$ is a member of ZA, then $\sim \varphi$ also is a member of ZA. $\theta, \varphi,(\sim \varphi)$ are beliefs, $[\theta \rightarrow \varphi]$ is a designation of cognitive implication (e. g. mice come from dirt), and ZA is a set of beliefs A (Koj 1998, 47). The entire model, then, is a system of, most often, unclearly spelled out beliefs, as those beliefs are a group of highly abstract assumptions about the world. That model drives human perception and is a benchmark in case of uncertainty and variability of phenomena.

The ability to reason pairs with the necessity of imagination. This leads each human to accept dialetheia in thinking. The general explanation of this fact is, as Józef Maria Bocheński noted, that every human has a world view (ZA in our terms) but it is not possible to hold a scientific worldview (where all sentences are true). Thus, human reasoning is related to either the causal mechanisms or fictional concepts of the world (or higher-level fictions without any reference to the world).

The ethical tale is a system of reasonings based on an individual's experience and is intrinsic to the individual's model of the world. We call it a tale because it is a reasoning in the form of narration. The tale comes from the sense of good and bad, which allows 
treating others in certain ways. It is not that ethical sentences have no meaning, and certainly they cannot be disposed of from our worldview; they are very deeply embedded in it. It is especially visible at the social level where people's exclusive needs collide with the scarcity of resources.

The problem with ethical tales lies in their vague reference to the ever-changing world. From a semiotic point of view, ethical norms are universal and uncompromising when it comes to their content. They seem clear and sure to those who hold them. Thanks to abstraction and fiction-manipulating, people are capable of creating ethical norms without any reference to reality i.e. on the basis of their narrow autopsy. Global thinking (by abstraction) in local conditions and the actions following it work, more or less. It is opposite in case of global thinking in global conditions (a characteristic of decisionmakers, planners and politicians). One needs to remember that it has its origin in the local conditions, and because of that origin meets some constraints that are impossible to overcome and are related to the uncertainty underlying it (see section 4).

Ethical reasonings are related to other types of reasoning, especially to descriptive reasonings of what exists. David Hume generalized one of the rules for validity of syllogisms to the following form: there cannot be terms in the conclusions, which are not there in the premises. "Under this rule it is not allowed to make obligatory statements in conclusion based on descriptive statements in premises" (Koj 1998, 47). The basis for that dictum is the difficulty to find descriptive statements falsifying obligatory statements. Considering the obligatory statement "Do not kill", it is not possible to falsify it, even by means of dieletheia like: "People kill and people do not kill". The conclusions drawn from this fact are that: 1) obligatory statements lack descriptive content, 2) they do not result from descriptive statements and 3) are not validated by them (Koj 1998, 48).

The strict division between obligatory and descriptive statements seems, however, to be a mistake. Full disjunction between axiological and empirical notions is not possible, because ethical statements consist of two parts. The first part states that there is or there is not a certain state of affairs and this part can have a truth value. The second part is an expression of beliefs in regard to the state of affairs from the first part; it is a judgment. What seems critical, then, to fully understanding the ethical tale is to clearly explicate its ontological assumptions as ethical evaluations seem to strongly supervene upon those assumptions. An ethical tale that assumes a highly epiphenomenal description of the world makes a narrative mistake. In effect, it ends up with a system of obligations that does not fit in with the real world but with the virtual world of someone's imagination. This is due to the fact that people abstract from reality in their evaluations, the result of which are catalogues of absolute, universal and categorical rules. They do not take into account that "in the expanding area of moral experience what used to be simple now becomes complex, apparently homogeneous situations become diverse; moreover, the language in which moral norms are formulated evolves, the meanings of terms change" (Czeżowski 1965,124). A priori ethical systems assuming an ultimate set of moral norms 
(or even one supreme norm from which the other norms follow) can be compared to a priori theories in natural sciences: both are exposed to the danger of falling afoul with experience (Czeżowski 1965, 124-125).

A paradox arises then: a human speaks about the ever-changing reality in terms of universal and absolute language. In order to remove that paradox, the ethical tales need to be built in continuous reference to the experience; and the experience means incomplete models taking into account that decentralized knowledge, for example, implies decentralized decision-making (Czeżowski 1965, 124). ${ }^{24}$ This, in turn, is connected to the auto-criticism and rigorous analysis of our theories.

\section{References}

Anderson T. L., Benson B., T. E. Flanagan T. E. (Eds.) 2006. Self-determination. The Other Path for Native Americans. Stanford: Stanford University Press.

Benson B. L. 1989. „Enforcement of Private Property Rights in Primitive Societes: Law without Government," The Journal of Libertarian Studies IX(1):1-26.

Block W. E., Futerman A. G., \& Farber R. 2016. "The Legal Status of the State of Israel: A Libertarian Approach," The Indonesian Journal of International \& Comparative Law (June):435-553.

Bocheński J. M. 1994. Bełkot [Gibber], in idem, Sto zabobonów [A hundred superstitions] (pp. 28-29). Kraków: Philed.

Chamlee-Wright E. \& Storr V. H. 2009. “'There's No Place Like New Orleans': Sense of Place and Community Recovery in the Ninth Ward After Hurricane Katrina," Journal of Urban Affairs 31(5): 615-634.

Chamlee-Wright E. \& Storr V. H. 2010. "Expectations of Government's Response to Disaster," Public Choice 144:253-274.

Cohen G. A. 1995. „Self-ownership, World-ownership, and Equality,” in idem, Selfownership, Freedom, and Equality (pp. 67-91). New York: Cambridge University Press.

Crean A. 2010. "Humean Humility," Logical Analysis and History of Philosophy" 13:17-37.

Czeżowski T. 1989. „Etyka jako nauka empiryczna” [Ethics as an empirical science], in idem, Pisma z etyki i teorii wartości (pp. 97-104). Warszawa: Ossolineum.

Czeżowski T. 1965. Konflikty $w$ etyce, in idem, Filozofia na rozdrożu. Analizy metodologiczne (pp. 121-129). Warszawa: PWN Editions.

24 We cannot reduce our experience to a narrow autopsy. We need to make attempts to analyze questions from various points of view. An example of such an attempt could be Susan Haack's foundherentism. 
Dennett D. 2007. „What RoboMarry Knows,” in T. Alter \& E. Walter (Eds.), Phenomenal Concepts and Phenomenal Knowledge. New Essays on Consciousness and Physicalism (pp. 15-31). New York: Oxford University Press.

Falk D. 2016. "New Support for Alternative Quantum View," Quanta Magazine/ URL: <https://www.quantamagazine.org/20160517-pilot-wave-theory-gainsexperimental-support/>

Friedman D. 1989 (Orig. 1970). The Machinery of Freedom. Guide to a Radical Capitalism. La Salle, IL: Open Court.

Friedman D. 1994. "A Positive Account of Property Rights," Social Philosophy and Policy 11(2):1-16.

Fuster J. M. 2013. The Neuroscience of Freedom and Creativity. Our Predictive Brain. New York: Cambridge University Press.

Glennan S. S. 1996. "Mechanisms and The Nature of Causation," Erkenntnis 44:49-71.

Glennan S. S. 2002. “Rethinking Mechanistic Explanation,” Philosophy of Science 69:342353.

Glennan S. S. 2005. "Modeling Mechanisms," Studies in the History and Philosophy of the Biological and Biomedical Sciences 36:375-388.

Glennan S. S. 2010. "Ephemeral Mechanisms and Historical Explanation," Erkenntnis 72(2):251-266.

Glimcher P. W. 2003. Decisions, Uncertainty, and the Brain. The Science of Neuroeconomics. London: The MIT Press.

Gold J. I. \& Shadlen M. N. 2007. "The Neural Basis of Decision Making," The Annual Review of Neuroscience 30:535-574.

Greniewski H. 1959. Elementy cybernetyki sposobem niematematycznym wyłożone [The elements of cybernetics explicated in non-mathematical way]. Warszawa: PWN.

Gryziński M. 2002. Sprawa atomu. Warszawa: Homo-Sapiens.

Hayek F. A. 1978 (Orig. 1969). The Constitution of Liberty. Chicago: China Social Sciences Publishing House.

Hasnas J. 2008. „The Obviousness of Anarchy,” in R. Long \& T. Machan (Eds.), Anarchism/ Minarchism: Is a Government Part of a Free Country? (pp. 111-131). Aldershot: Ashgate Press.

Kahneman D., Slovic P., \& Tversky A. (Eds.) 1982. Judgment under Uncertainty: Heuristics and Biases. Cambridge: The Press Syndicate of the University of Cambridge.

Keynes J. M. 2013 (Orig. 1936). The General Theory of Employment, Interest and Money. Cambridge: Cambridge University Press.

Klawiter A. 2004. "Powab i moc wyjaśniająca kognitywistyki," Nauka 3:101-120. Koj L. 1998. Powinności w nauce. Lublin: Wydawnictwo UMCS Editions.

Kossecki J. 2001. "Relacja 'prawda-fałsz' w ilościowej i jakościowej teorii informacji," The Peculiarity of Man 6:349-386. 
Kuhlmann M. \& Glennan S. S. 2014. "On the Relation between Quantum Mechanical and Neo-mechanistic Ontologies and Explanatory Strategies," European Journal for Philosophy of Science 4(3):337-359.

Lem S. 1964. „Modele i rzeczywistość”, in idem, Summa Technologiae (pp. 151-155). Kraków: Wydawnictwo Literackie.

Long R. T. 2006. "The Justice and Prudence of War: Toward A Libertarian Analysis," Reason Papers 28:51-60.

Łukasiewicz J. 1987. O zasadzie sprzeczności u Arystotelesa. Warszawa: PWN.

Marx K. 2017 (Orig. 1875). Kritik des Gothaer Programms. URL: <https://marx-wirklichstudieren.net/2012/11/27/karl-marx-kritik-des-gothaer- programms/> (PDF, 36 Seiten).

Minardi J.-F. 2017. Hong Kong: The Ongoing Economic Miracle. URL: <http://www.iedm. org/46514-hong-kong-the-ongoing-economic-miracle>

Moyo D. 2009. Dead Aid: Why Aid Is Not Working and How There is Another Way for Africa. Suffolk: Penguin Books.

Narveson J. 1997. "Egalitarianism: Partial, Counterproductive and Baseless," Ratio (New Series) X(3):280-295.

Norton R. 2017. „Unintended Consequences,” in D.R. Henderson (ed), The Concise Encyclopedia of Economics. URL: <http://www.econlib.org/library/Enc/ UnintendedConsequences.html>.

Nozick R. 1999 (Orig. 1974). Anarchy, State and Utopia. New Jersey: Blackwell.

Pranke P. \& Zečević M. 2016. Handel interregionalny od X do XII wieku. Europa Środkowa, Środkowo-Wschodnia, Półwysep Skandynawski i Półwysep Bałkański. Studium Porównawcze. Toruń: Wydawnictwo Naukowe Uniwersytetu Mikołaja Kopernika.

Ostrom E. 1990. Governing the Commons. The Evolution of Institutions for Collective Action. Cambridge: Cambridge University Press.

Priest G. \& Berto F. 2017. "Dialetheism," The Stanford Encyclopedia of Philosophy (Spring Edition), ed. by E. N. Zalta. URL: <https://plato.stanford.edu/archives/spr2017/ entries/dialetheism/>.

Shalins M. 2008. „Adams and Hobbes as Thucydideans,” in: idem, The Western Illusion of Human Nature (pp. 5-97). Chicago: Prickly Paradigm Press.

Strzelecki J. 2014. „Jakościowa teoria informacji a koncepcje prawdy [Qualitative Theory of Information and Conceptions of Truth]," Humanistyka i Przyrodoznawstwo 20:177-191.

Sugden R. 2005 (Orig. 1986). The Economics of Rights, Co-operation and Welfare. London: Palgrave Macmillan.

Taleb N. N. 2001. Fooled by Randomness. The Hidden Role of Chance in the Markets and in Life. New York - London: Texere.

Taleb N. N. 2007. The Black Swan. The Impact of the Highly Improbable. New York: Random House. 
Tervo D. G. R., Proskurin M., Manakov M., Kabra M., Vollmer A., Branson K., \& Karpova A. Y. 2014. "Behavioral 31 Variability through Stochastic Choice and Its Gating by Anterior Cingulate Cortex," Cell 159(1):2-132.

Tkaczyk M. 2014. "Grahama Priesta metoda uzasadniania tezy dialeteizmu," Warszawskie Studia Teologiczne XXVII(2):23-35.

Quine W. V. Q. 1961 (Orig. 1953). "Logic and the Reification of Universals," in idem, From a Logical Point of View (pp. 102-129). New York, Hagerstown - San Francisco London: Harper \& Row Publishers.

Warren J. 2011 (Orig. 1846). „Equitable Commerce,” in idem, The Practical Anarchist. Writings of Josiah Warren (pp. 54-98). New York: Fordham University Press.

Waterman T. T. 1920. Yurok Geography. Berkeley: University of California Press.

Widerquist K. \& McCall G. 2015. „Myths about the State of Nature and the Reality of Stateless Societes," Analyse \& Kritik 01+02:233-257.

Varela F. 1999. Ethical Know-How. Action, Wisdom, and Cognition. Stanford: Stanford University Press. 
Przemysław Zonik (Lublin), Joanna Zonik (Lublin)

\title{
Society, Dispersed Knowledge and Uncertainty Toward Ethical Tales
}

\begin{abstract}
In this article the assumptions of one of the versions of the common good concept in terms of the dispersion of knowledge and uncertainty are analyzed. The article also aims at showing the consequences in regard to moral attitudes in politics and economics which are drawn on the basis of the concepts of this type. In the first part I expound the ontological assumptions which are the basis for the analysis. In the second part the concept of common good in terms of its own assumptions and in relation to the ontology developed in this article is discussed. In the third part I consider some general thoughts about the structure of the ethical tales and their reference.
\end{abstract}

Keywords: cybernetics; theory of mechanism; dispersed knowledge; uncertainty; politics; common good; ethical claims and reality; ethical tales.

Ethics in Progress (ISSN 2084-9257). Vol. 11 (2020). No. 1, Art. \#6, pp. 99-119. Creative Commons BY-SA 4.0

DOI:10.14746/eip.2020.1.6 